\title{
JUSTICE DIALOGUE IN THE PROCESS OF CRIMINAL JUSTICE ${ }^{\Omega}$
}

\author{
Teguh Ujang Firdaus Bureni \\ Universitas Nusa Cendana, Kupang - Indonesia \\ E-mail: teguhbureni17@gmail.com
}

\begin{abstract}
Criminal justice upholds law and justice based on material truth revealed in justice dialogue. Nowadays, the verdict of criminal justice does not reveal material truth. It is strongly presumed that there are some problems in justice dialogue. This normative juridical research with philosophical and conceptual approach describes the problems of justice dialogue in the process of criminal justice. Justice dialogue happened in the case of Blasphemy by Ahok and the case of Cocoa Stealing by Mina. The implementation of justice dialogue today is not in line with the principles of dialogue such as doubtful assumptions, freedom to have dialogue, imbalance chance of dialogue, sufficient attention, and best idea acceptance. Dialogue principles are violated in the case of blasphemy like sufficient attention and best idea acceptance. In the case of cacao stealing, the breaking of dialogue principles is doubtful assumptions, freedom to have dialogue, sufficient attention, and best idea acceptance. As a result, law and justice enforcement in criminal justice is not based on material truth.
\end{abstract}

Keywords: criminal justice, dialogue principles, justice dialogue

\begin{abstract}
Abstrak
Peradilan pidana menegakan hukum dan keadilan berdasarkan kebenaran materiil yang terungkap dalam dialog keadilan. Putusan peradilan pidana kini tidak mengungkapkan kebenaran materiil. Kuat dugaan terdapat masalah dalam dialog keadilan. Penelitian yuridis normatif dengan pendekatan filsafat dan konsep ini mendeskripsikan permasalahan dialog keadilan dalam proses peradilan pidana seperti dialog keadilan dalam perkara Penistaan Agama oleh Ahok dan perkara Pencurian Kakao oleh Mina. Pelaksanaan dialog keadilan dewasa ini tidak sesuai dengan prinsip berdialog seperti ragu atas asumsi sendiri, kebebasan berdialog, keseimbangan kesempatan berdialog, perhatian memadai, dan penerimaan gagasan terbaik. Dialog keadilan perkara penistaan agama terdapat penyimpangan prinsip berdialog yaitu perhatian yang memadai pada setiap gagasan dan penerimaan gagasan terbaik. Pada perkara pencurian kakao, penyimpangan prinsip berdialog antara lain ragu atas asumsi sendiri, kebebasan berdialog, perhatian memadai, serta penerimaan gagasan terbaik. Dampaknya, penegakan hukum dan keadilan dalam peradilan pidana tidak didasarkan kebenaran materiil.
\end{abstract}

Kata kunci: dialog keadilan, peradilan pidana, prinsip berdialog,

\section{Introduction}

Indonesia is a legal state. Lon Fuller ${ }^{1}$ explains that the important principle of 'rule of law' is the existence of guarantee for the independence of judiciary, upholding justice based on the right legal implementation and it is accessible to all parties.

$\Omega$ Teguh U. F. Bureni, "Dialog Keadilan Dalam Proses Peradilan Pidana", Thesis of Magister of Law, 2017, Post-graduate of UNDANA Kupang.

1 Frans J. Rengka, "Intitusi Peradilan, Hakim, dan Perannya dalam Masyarakat Lokal", Jurnal Aequitas luris, Vol. 1 No. 1 July 2007, p. 1.
Court in Constitution contained in Chapter IX on Judicial Power ${ }^{2}$ in article 24 paragraph (1) states that judicial power is an independent power to uphold law and justice, and paragraph (2) explains that judicial power is held by Supreme Court and its subordinate courts as well as Constitutional Court. Judicial power is charged in enforcing law and justice through judicial proceedings. Here happens justice dia-

Josef M. Monteiro, "Putusan Hakim Dalam Penegakan Hukum Di Indonesia", Jurnal Hukum Pro Justisia, Vol. 25 No. 2, April 2007, p. 131 
logue to obtain material truth for the sake of law and justice enforcement.

Justice dialogue must be implemented based on the right principles of dialogue. The requirements to have dialogue according to $\mathrm{Pe}$ ter Sange and Habermas are; ${ }^{3}$ all the involved parties in having dialogue must regard each other as partner, freedom to have dialogue, equal opportunity to express arguments, and adequate attention to any arised idea. The accepted idea is the idea with better argument. Furthermore, these principles must be properly understood and applied by all parties in justice dialogue. The problem is that today the verdict of judicial process does not provide justice for justice seekers and public. For example, First, Decision Number 1537/Pid.B/2016/PN.Jkt.Utr on Blasphemy Case, Basuki Tjahja Purnama was sentenced 2 years imprisonment for issuing utterances related to al-Maidah verse 51 , although there are no explanation and reason for the judge's reasoning to reject arguments and opinions of the prosecutor. Second, Decision Number 247/Pid.B/2009/PN.PWT on Three Cocoa Pods Stealing $\mathrm{Case}^{4}$, Minah, an illiterate grandmother was sentenced 1 month and 15 days with a trial of 3 months for committing to steal 3 cocoa pods owned by PT Rumpun Sari Antan (RSA) although there was no intention of having cocoa pods and she had returned to the foreman by apologizing. The disclosure of verdict demonstrates the achievement of procedural justice while substantive justice has not been achieved. Allegedly, there is a problem in the process of implementation of justice dialogue. Thus, the interesting legal issues to be discussed in this article are: First, How is justice dialogue in the process of criminal justice? and Second, How are the justice dialogue in Decision Number 1537/Pid.B/2016/PN.Jkt.Utr on Blasphemy and Decision Number 247/Pid.B/

Frans J. Rengka, "Dialog Hukum dan Keadilan Dalam Proses Peradilan Pidana (Studi Tentang Peradilan Pidana Sebagai Forum Dialog Dalam Kasus Pidana Politik Masa Orde Baru), Legal Science Doctoral disertation, UNDIP Semarang, p. 11.

4 Sunarto, “Asas Legalitas Dalam Penegakan Hukum Menuju Terwujudnya Keadilan Substantif" Jurnal MasalahMasalah Hukum, Vol. 45 No. 4, October 2016 Edition, p. 252.
2009/PN. PWT on the stealing of three cocoa pods?

\section{Research Method}

This is philosophical-normative ${ }^{5}$ juridical research applying conceptual and philosophical approaches toward legal material collected by snowball technique. Moreover, it will be described deductively to address the issue of Justice Dialogue in the Criminal Justice Process.

\section{Discussion \\ Justice Dialogue in the Process of Criminal Justice}

Justice Dialogue is a series of action in court in the form of communication either spoken like exchanging questions and answers or written between the parties in the dialogue about law applied to achieve the same reflection on the truth of the encountered case based on the law and values of justice in paying attention to the right principles of dialogue.

The implementation of justice dialogue must follow the right principles of dialogue namely: first, doubtful on their own assumptions. It is defined as the form of openness in learning and understanding the arguments of all parties. Second, all parties regard each other as partner. It is expected this can avoid selfishness and hostility so that they do not regard others as enemy. Third, all parties are only facilitator. The parties involved in justice dialogue are not allowed to bring their own personal interest in having dialogue. The example of breaking this principle is the defender attempts to free his or her client even the client is wrong only for the sake of popularity, instead of attempting to get fair penalty for the client. Plaintiff tries to prove his or her indictment because of individual egocentrism and title promotion. The judge ignores substantive justice unsure found for the sake of enforcing the law. Fourth, there must be freedom to have dialogue. The breaking of this principle happens when investigating the witness. The questions asked by the parties

\footnotetext{
5 Ridwan Khairandy, "Landasan Filosofis Kekuatan Mengikatnya Kontrak", Jurnal Hukum lus Quia lustum, Vol. 18, October 2011 Special Edition, p. 39.
} 
in justice dialogue are often directing and cornering one party. It is often found that there are witnesses whose answers and explanation have been set by each party. Fifth, the equal opportunity to express arguments. In fact, justice dialogue takes place in court undergo limitation of expressing arguments. For example, the number of witness in BAP is 5 people. However, after investigating the fourth witness, the party who proposes the witness state that it is enough so that the fifth witness is not heard. Sixth, each idea is given sufficient attention. Totality means as the guide of material truth and it is obtained if there is sufficient attention on each idea expressed. Seventh, the idea with the best argument is accepted. The acceptance of idea with the best argument is based on the ability to defend idea with the proofs of the truth.

The process of justice dialogue in solving the case can be seen from two conditions which are given condition and ideal condition. Justice dialogue in existing condition is not based on the right principles of dialogue. It is more emphasizing individual egocentrism, not being opened in understanding and accepting arguments, cornering one party in having dialogue, and not giving equal opportunity in having dialogue. This kind of justice dialogue causes justice dialogue in the process of criminal justice tend to concern personal interest as the form of individual egocentrism of each party. As the result, the truth delivered by one party in the dialogue cannot be accepted and does not get sufficient attention to express material truth from the case. It exacerbates with the act of cornering one party and the absence of equal opportunity to have dialogue in criminal justice process.

Ideally, justice dialogue is based on the right principles of dialogue namely doubtful on their own assumptions; each party is partner; each party is only facilitator; there is freedom to have dialogue; there is equal opportunity to express arguments; there is sufficient attention for all ideas expressed; the best idea will be accepted.

Under ideal condition, justice dialogue aims to reveal material truth as the foundation to provide substantive justice condition. Lawrence Friedman ${ }^{6}$ believes that justice is divided into two; procedural ${ }^{7}$ and substantive justice. ${ }^{8}$ Procedural justice is rules that are not only fair and neutral, but also honestly conducted. The rules are in line with appropriate standard of procedure and neglect any differentiation of race, class or social status. Substantive justice is justice that can be witnessed and felt by the people. It stands on the previous meaning where procedural justice has been achieved since every step in the court has been done. Achieving procedural justice raises question for substantive justice. It can be realized when there is fair law coming from the values of people in neutral condition.

In Indonesia, justice shows similarity to substantive justice where social justice mention in the fith principle of Pancasila "Social justice for all Indonesian". 9 Pancasila is the national principle as well as fair justice since it comes from values and norms of people in given condition. Rules which challenge Pancasila have to be alienated or revised. The rule of law on justice which does challenge Pancasila will process justice to fulfill social justice that is close to substantive justice.

Substantive justice in the process of justice can be processed to law system by Lawrence $M$. Friedman ${ }^{10}$ that consists of culture, substance and structural components. In culture components and substance component, there is no problem in achieving substantive justice. This is due to the culture of law in Indonesia where Pancasila clearly accommodates substantive justice under the fifth principle. Compo-

6 Yunus P.S. Bureni, "Pembentukan Peraturan Daerah Dalam Upaya Mencapai Keadilan substantif", Thesis of Magister of Law, 2011, Post-graduate of UNDANA Kupang, p.42

7 Bambang Sutiyoso, "Mencari Format Ideal Keadilan Putusan Dalam Peradilan “, Jurnal Hukum lus Quia lustum, Vol 17 No. 2, April 2010, p. 227.

8 Yunus P.S. Bureni, "Moralitas Pembentukan Peraturan Daerah Dalam Upaya Mencapai Keadilan substantif", Jurnal Legislasi Indonesia, Vol.10 No. 2, June 2013, p. 127.

9 Anwar c, "Problematikan Mewujudkan Keadilan Substantif Dalam Penegakan Hukum Di Indonesia”, Jurnal Konstitusi, Vol. 3 No. 1, June 2010, p. 130.

10 Emy Hajar Abra, "Konstruksi Sistem Hukum Indonesia”, Jurnal Dimensi Universitas Riau Kepulauan Batam, Vol. 5 No. 3,2016 , p. 6 
nents of substance make substantive justice as a goal since each regulation provides the spirit of Pancasila. There is no trouble in culture and substance components; thus, the writer believes that there is problem in structural component. To be specific, there is no implementation of justice dialogue based on the appropriate dia-logue principle in the process of justice in the court.

The problem of structural component can be seen clearly in the process of justice dialogue in court proceedings which are: first, in the court, the prosecutor never justifies the defense points despite of the truth. On the contrary, the defense tries to free the client despite its guilt instead of asking for punishment. In this case, prosecutors and defenders are enemies in trials instead of facilitators to resolve cases. Second, there is no freedom in dialogue because of setting up of witnesses. Witnesses have been notified which issue that should not be disclosed or must be disclosed. Meanwhile, the questions in dialogue were cornering and leading the witnesses in answering. Moreover, formulation of the article has always been the topic of dialogue as the proof while the length of punishment has never been discussed. As a result, the punishment imposed was not balanced with the deeds.

In explaining this chapter, the author divides it into two conditions; given and ideal conditions. In given condition, the justice dialogue process happening in the trial is not conducted based on the right dialogue principles. The justice purpose is only to fulfill every justice process stage in the trial. Consequently, the dialogue topic is only verification of the articles implemented while the punishment threat is not discussed. This kind of justice only reaches the procedural justice.

In ideal condition, the justice process is conducted based on the right dialogue principles. It aims to require the procedural justice and seek material truth as the judge's base in deciding the verdict. In addition, the dialogue topics are the article verifications and the punishment threat.
The question is can the justice dialogue as an effort in justice process reach the substantive justice? It can be explained in two conditions namely given and ideal conditions. In given condition, the justice dialogue does not function as it should be. The parties in justice dialogue have dialogue not based on the right dialogue principles. There are individual egocentrism, personal interest orientation, no openness, centering and directing behaviors, standing for certain party in the discussion, and no equal opportunity in delivering arguments. Consequently, the justice dialogue only fulfills the procedural stage and the topic is limited on the verifications of articles implemented in that case.

In the ideal condition, the justice dialogue process is based on the right dialogue principles, so it fulfills the procedural stage and it reveals the legal facts as the material truth. Moreover, the dialogue topics are the verifications of law articles and the punishment threat. The fulfillment of procedural stage, the revelation of material truth, and the discussion on punishment shows that the procedural justice and substantive justice have been achieved through the instrument of justice dialogue.

Justice Dialogue in Decision Number 1537/ Pid.B/2016/PN.JktUtr. on Blasphemy and Decision Number 247/Pid.B/2009/PN. PWT on Three Cocoa Pods Stealing.

By analyzing Decision Number 1537/Pid. B/2016/PN.Jkt.Utr on Blasphemy, it can be seen that the justice dialogue does not totally apply the right dialogue principles. There are several dialogue principles in justice dialogue that violate the right ones. The violation of dialogue principles are, first, sufficient attention toward every idea, the ideas from the defendant's expert which stated that understanding a statement must be observed completely, wholly, and not interpreted by part of sentence, and not considered by the judge. Second, the defendant's explanation about his knowledge on Al-Maidah verse 51, according to Gusdur's statement which states that it is allowed to elect non-moslem government leader 
not considered by the judge. Third, the defendant's ideas about statement of "do not be lied" was not aimed to disgrace Islam yet to remind the people so that they cannot be fooled by those who use Al-Maidah verse 51 for certain interest.

By observing the defendant's acknowledgement, it is true that he did not mean to disgrace Islam. Instead, the defendant ensured the people that the fish cultivation program will keep running though he is not a governor anymore, possibly because of the political persons who disliked him then incited others not to elect non-moslem prospective governor using alMaidah verse 51 .

On the other hand, the public prosecutor, defense and judges did not pursue the truth material with the meaning of the word "lied by using Al-maidah". Therefore, the judges' consideration on the meaning which receives the statements from the expert of public prosecutors without giving any reason to reject the idea of the accused expert, according to the writer, is a violation of the principle that gives the same attention to every idea.

Principles of ideas with the best arguments are the ones received. The consideration of the verdict on blasphemy is seen when the judge follows the opinion of the prosecutioner and the prosecutor's witness regarding the phrase, "do not believe" to declare it as a blasphemy and put aside the expert opinion of the defendant to see if the sentence is in full context. The verdict continues without the panel of judges' consideration why the opinion of the expert and witness of the prosecutor is better than the opinion of the defendant's witness and expert. The panel of judges did not consider why they rejected the argument of the defendant based on his understanding of Al-Maidah verse 51 under the enlightenment of Gus Dur.

The panel of judges in considering the deliberate elements has considered the fulfillment of deliberate elements based on deliberate attitude of the defendant to express the phrase "do not believe" without considering whether the defendant's expression is based on deliberate stigmatization of religion or not.
In their legal considerations, the judges did not distinguish the meaning of being lied by using Al-Maidah verse 51 and the meaning of being lied to with of Al-Maidah verse 51 . This certainly has a different meaning. If being lied by the use Al-Maidah then meaning will be the use of Al-Maidah verse 51 to deceive others and done by someone. While, being lied to with alMaidah verse 51 , then the lie is the Al-Maidah verse 51 . As a result, material truth in justice dia-logue is not revealed, thus, panel of judges does not decide based on material justice.

Justice Dialogue in Decision Number 247/ Pid.B/2009/PN.PWT on Three Cocoa Pods Stealing is perceived to have deviation of true dialogue principle on the process of justice dialogue in this decision. Thus, the principle doubts on its own assumption. The ongoing justice dialogue is lack of openness in the prosecution to admit that the defendant placed the cocoa fruit she had picked on the ground, under the cocoa tree while waiting for the foreman to ask for permission to own the three cacao fruit as a legal fact. The prosecutor is only guided by the fulfillment of the formulation of theft offense in Criminal Code (article 365), which is first to take, namely holding the fruit of cocoa and picking. Therefore, cocoa is in the power of the defendant. However, the element of laying cocoa fruits on the ground on request of the foreman's permission is not accepted by the prosecutor and judge as a material truth. Second, something which is three pieces of cocoa picked by the defendant. Third, the purpose of having the goods is seen from the statement of the grandmother who wants to make the three cocoas as the seeds are illegal.

There should be a principle of adequate attention to every idea; but in reality, not every idea in a justice dialog related to theft case of three cocoas by the defendant is given adequate attention. The dismissed idea was the defendant's statement that "after picking, the defendant put the cocoa fruit under the cocoa tree while waiting for the foreman to ask for permission to own the cocoa. When the foreman finds the cocoa fruit under the cocoa tree and asks who is picking, the defendant admits that 
the defendant is picking them to be used as seed but if she is not allowed by the foreman, he can bring it back. The defendant has also been advised by the foreman and the defendant apologized."

The above statement proves that it is actually the defendant who picked the three cacao fruits so that the element of taking something (goods) away has been fulfilled. Yet, the intention to own something against the law has not been fulfilled. It is viewed from the attitude of the grandmother named Minah who still put the cacao fruits under the cacao tree with the intention of waiting for the foreman to ask permission to own it. It is proven when the foreman did not allow. The defendant allowed the foreman to bring the three cacao pods and also apologized.

The principle of ideas acceptance is with the best argument. In the verdict, the judges considered justifying that the defendant committed the stealing because in pleading the defendant admitted her wrongdoing which had taken the cacao fruits. The defendant's acknowledgment was due to illiteracy, ignorance of law and inability to speak Indonesian. In researcher's point of view, the defendant gave a guilty plea to take cacao in this case, actually is the recognition that the defendant indeed took the cacao but the element of intention to own cacao unlawfully has not been revealed and proven yet. It is because in this case the defendant put the cacao fruits under the cacao tree while waiting for the foreman to ask permission. If the defendant intended to own them against the law, the defendant certainly would not put the picked-cacao pods under the tree while waiting for the foreman because the defendant had a chance to take it secretly and hid it.

The impact of these unfulfilled principles is the material truth that should be revealed in justice dialogue is unrevealed. As the result, the judges did not impose the verdict based on material truth.

\section{Conclusion}

The process of justice dialogue must follow the principles of dialogue correctly, name- ly; doubtful on their own assumptions, the parties are partners of dialogue and are just facilitators, freedom of having dialogue, equal opportunity to express arguments, sufficient attention and acceptance of the best idea. However, the process of justice dialogue that takes place in court is in fact incompatible with the principles of the dialogue properly. It results the non-disclosure of material truth as the basis of the verdict for judges. Consequently, procedural justice is achieved but not substantive justice.

In the justice dialogue of the blasphemy case, there are deviations of the principle of dialogue that are adequate attention and acceptance of the best idea. Meanwhile, in justice dialogue of cacao stealing case, deviations of the principle of dialogue include doubtful on their own assumptions, adequate attention to every idea and acceptance of best idea. The failure of justice dialogue based on the principle of dialogue resulted in the non-disclosure of material truth as the basis of the judge's verdict; therefore substantive justice is not achieved.

\section{Suggestions}

It is a necessary to have correct understanding of judicial dialogue and open attitude and the willingness of the parties to follow the principles of dialogue properly. In the case of revealing material truth as the basis of judges in delivering verdicts reaching procedural justice and substantive justice, the parties involved in justice dialogue on the criminal justice process should conduct justice dialogue by adhering to the principles of dialogue in the right way.

\section{References}

Abra, Emy Hajar. "Konstruksi Sistem Hukum Indonesia". Jurnal Dimensi Universitas Riau Kepulauan Batam. Vol. 5 No. 3, 2016. Pp. 1-10;

Anwar C. "Problematikan Mewujudkan Keadilan Substantif dalam Penegakan Hukum di Indonesia”. Jurnal Konstitusi. Vol. 3 No. 1. June 2010. Pp. 127-140; 
Bureni, Yunus P.S. "Moralitas Pembentukan Peraturan Daerah dalam Upaya Mencapai Keadilan substantif". Jurnal Legislasi Indonesia. Vol.10 No. 2. June 2013. Pp. 123-132.

2011. Pembentukan Peraturan Daerah dalam Upaya Mencapai Keadilan. Thesis. Magister Program of Law. Postgraduate. Kupang: UNDANA;

Khairandy, Ridwan. "Landasan Filosofis Kekuatan Mengikatnya Kontrak". Jurnal Hukum Ius Quia lustum. Vol. 18. Special Edition October 2011. Pp. 36-55;

Monteiro, Josef M. "Putusan Hakim dalam Penegakan Hukum di Indonesia". Jurnal Hukum Pro Justisia. Vol. 25 No. 2. April 2007. Pp. 130-139;

Rengka, Frans J. "Intitusi Peradilan, Hakim, dan Perannya dalam Masyarakat Lokal”. Jur- nal Aequitas luris. Vol. 1 No. 1. July 2007;

Rengka, Frans J. 2003. Dialog Hukum dan Keadilan dalam Proses Peradilan Pidana (Studi tentang Peradilan Pidana Sebagai Forum Dialog dalam Kasus Pidana Politik Masa Orde Baru). Disertation. Doctoral Program of Law. UNDIP Semarang;

Sunarto. "Asas Legalitas dalam Penegakan Hukum Menuju Terwujudnya Keadilan Substantif" Jurnal Masalah-Masalah Hukum. Vol. 45 No. 4. October 2016. Pp. 252258. DOI: $10.14710 / \mathrm{mmh} \cdot 45.4 .2016 .25$ 2-258;

Sutiyoso, Bambang. "Mencari Format Ideal Keadilan Putusan dalam Peradilan". Jurnal Hukum lus Quia lustum. Vol. 17 No. 2. April 2010. Pp. 217-232. DOI: 10.20885/ iustum.vol17.iss2.art4; 